Dept. of Biochemistry, Toxicology and Nutritional Deficiency, Animal Health Research Institute, Dokki, Giza.

\title{
EXPERIMENTAL STUDIES ON THE INFLUENCE OF CASEIN OR ACTIVATED CHARCOAL ON LEAD TOXICITY UPON FERTILITY
}

\author{
(With 7 Tables and 6 Figures)
}

By

\section{MAHA Z. ELABEDEIN GABER; ANSAM M. SALMAN* and KH.Z. DOKHAN**}

* Dept. of Immunity, Animal Health Research Institute, Dokki, Giza. ** Dept. of Pathology, Animal Reproduction Research Institute, Haram, Giza.

(Received at 10/3/2009)

\section{مها زين العابلين جابر ، انسام سلمان ، خالد زكى دخان

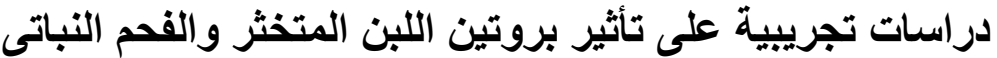

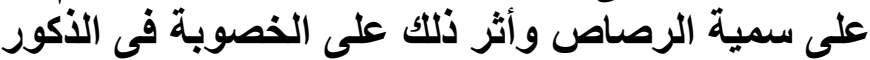

أجريت هذة الدراسة التجريبية على عدد 40 من فئر ان التجارب الذكور ولقد قسمت الى اربع

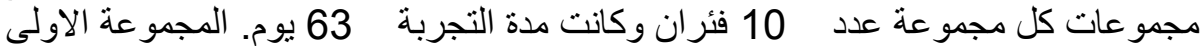

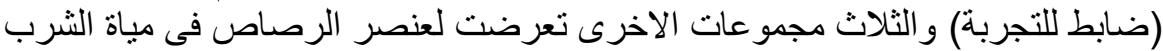

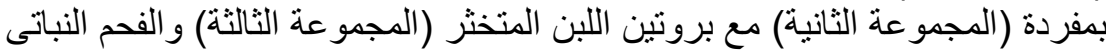

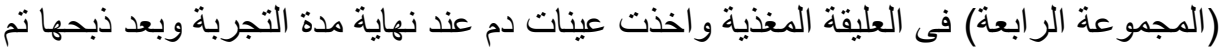

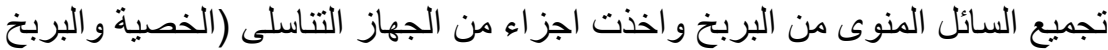

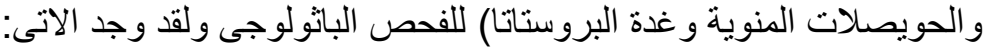

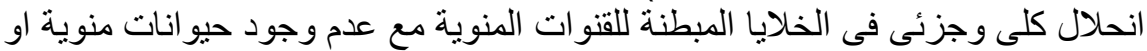

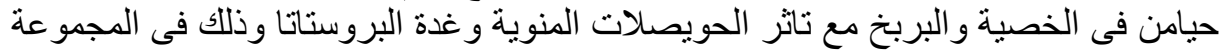

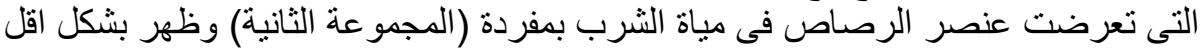
فى المجموعة التى تعرضت عنصر الرصن الرصاص فى مباة الثرب و الفحم النباتى فى العليقة

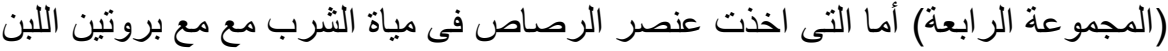

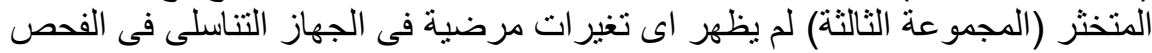

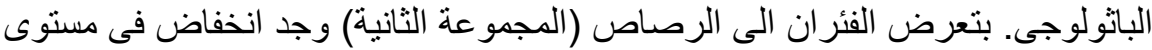

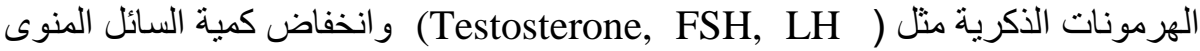

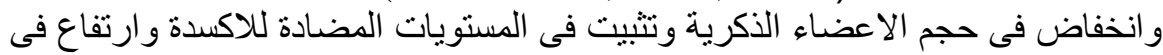

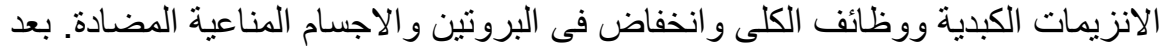

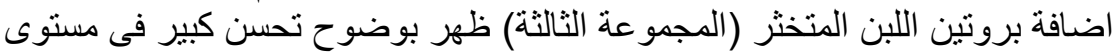

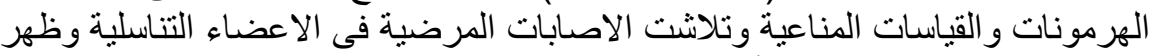
بشكل اقل من المجموعة التى أعطت عنصر الرصاص فئ مياة الثرب و الفحم النباتى 


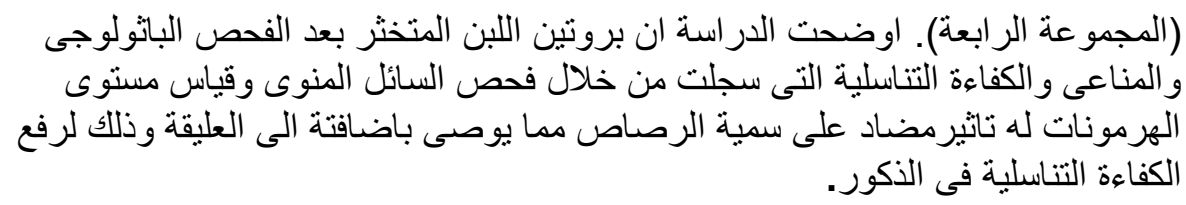

\section{SUMMARY}

Fourty male albino rats, were divided into four separate groups each of 10 rats. Group I was considered as control. Rats of other groups Gr II; III and IV were intoxicated by lead acetate at a dose of $0.5 \mathrm{gm} / 100 \mathrm{ml}$ in drinking distilled water for 63 days (Gr 11), in addition of casein at a concentration of $20 \mathrm{~g} / 100 \mathrm{~g}$ ration in (Gr III), and activated charcoal in a concentration $0.05 \mathrm{~g} / 100 \mathrm{~g}$ ration in (Gr IV). Exposure to lead acetate in Gr II resulted in suppressed spermatogenesis and hormonal levels in serum (testosterone, FSH and LH) with a highly significant decrease in weights and size of sexual organs as compared to the control (Gr I). The pathological changes of sexual organs in lead treated rats showed severe degenerative changes in the epithelium tubules. On the other hand these patholoigical investigation were improved in (Gr III) in casein treated rats. The results of immunological studies showed suppression of antioxidant levels lysozyme activity and nitric oxide production as a result of lead exposure in rats (Gr II). There was also a marked increase in malondialdehyde production as a result of lipid peroxidation. Kidney function and liver enzymatic activity were increased in Gr II as compared to Gr I In addition, the immunological studies revealed a significant decrease in serum total protein, gamma globulin and serum albumin as a result of immunosuppression effect of lead in Gr II. After treatment by casein or charcoal, it is obviously clear that casein can induce protective effects against lead toxicity nearly in most reproductive parameters and immunological states, while charcoal failed to improve the toxic effects of lead.

Key words: Toxicology, casein, activated charcoal, lead, fertility.

\section{INTRODUCTION}

Lead $(\mathrm{Pb})$ is one of the oldest known and most important environmental pollutants which can increase the health risk for human and animals by its toxic effects to many organ systems (Todd, 1994; Tuorma, 1995; Gidlow, 2004 and Simsek et al., 2008). Lead poisoning may affect body organs for several years even in the absence of 
continued exposure (Vig and $\mathrm{Hu}, 2000$ ). Most of old and recent studies have shown that reproductive toxicity is an important feature of lead toxicity. Lead causes infertility in male rats and mice (Puhac, et al., 1963 and Vorma et al., 1974), oligospermia and testicular degeneration in rats (Golubovich, et al., 1968) and teratospermia, hypospermia and asthenospermia in human (Lancranjan, et al., 1975). Metal lead can be transmitted through blood testes barrier and accumulate in testicular tissue induces a significant increase in apoptotic cell death in seminephrous tubules (Adhikari, et al., 2001 and Batra, et al., 2001). In addition, lead can alter prostate secretory function (concentration of zinc, acid phosphatase and citric acid, in the seminal fluid) (Alloway, 1990). Moreover, Murthy (1991) mentioned that in animal lead like other divalent cations can inhibit binding of dihydrotestosterone to specific receptors in the prostate and seminal vesicle. On the other hand lead alters a number of parameters of the host immune system and leads to increasing susceptibIlity to infections, autoimmune diseases and allergic manifestations. A number of studies documented that heavy metals are not only toxic for the organism but also may modulate immune responses (Krocova, et al., 2000). Lead poisoning has immunosuppressive effects on humoral responsiveness (Khanna and Johri, 1991) and on cell mediated immune response (Miller, et al., 1998). Moreover, lead decreases host resistance to infectious diseases (Lee et al., 2002) and induces immunotoxicity on macrophages with depression of phagocytosis, nitric oxide production and lysozyme activity (Krocova et al., 2000). The adverse effects of lead are associated with oxidative damage of lipids based on increase malondialdehyde content in blood and inhibition of antioxidant enzymes (Mateo, et al., 2003). Lead causes immunotoxicity of liver and kidneys, due to its accumulation in these organs with its cytotoxicity (De Francisco et al., 2003). Casein is a mixture of phosphoproteins occurring in milk and cheese, present to the extent of $3 \%$ in bovine milk, obtained by removing the cream from milk and acidifying the skimmed milk which causes casein to precipitate (Goyer and Mehman, 1977). A possible relationship between susceptibility to lead toxicity and dietary content of protein (such as casein) and certain amino acids has been observed according to Gontzeer et al. (1964). On the same manner Der et al. (1974) recorded that the protein -deprived lead exposed animals showed atrophy of the sexual organs and failure of spermatogenesis as well as increase susceptibility to infection. Activated charcoal (AC) denotes a material, which has an exceptionally high surface area and includes a large 
amount of microporousity. It is cheap, harmless and easily used. AC is produced from the controlled burning of wood or bone, which is then subjected to the action of an oxidizing gas such as steam or air at elevated temperature (EIlenhorn, 1997). This process enhances the adsorptive power of charcoal by developing an extensive network of fine pores. Ademoyero and Dalvi, (1983) and Jindal et al. (1994) used AC to reduce the toxic effects of aflatoxin in chicken. Cupic et al. (2003) recorded the effectiveness of $\mathrm{AC}$ in protection of animals poisoned with bromadiolone. The purpose of the present study was to compare the influence of casein as a main milk protein and activated charcoal (AC) as a physical antidote (adsorbent) agent to diminish risk of lead toxicity on male pathological reproductive system, hormonal profile and immune system.

\section{MATERIALS and METHODS}

\section{Chemicals:}

a) Lead $(\mathrm{Pb})$ : Lead acetate trihydrate ( $\mathrm{C} 4 \mathrm{H} 604 \mathrm{~Pb} 3 \mathrm{H} 20$ ) of molecular weight 379.33 was provided by Riedel Dehaen, Hannover, Gennany. Each one gram of $\mathrm{Pb}$ is found in 1.83079 of finelly powders of lead acetate (Fatma, 1992).

b) Casein: It is a white amorphous powder without odor or taste, very sparingly soluble in water and in nonpolar organic solvent and soluble in aqueous solutions of alkalies, of molecular weight 23.600 (Ribadeaudumas, 1972). Casein (pure form) was obtained from ElGomhorya Company, Egypt.

c) Activated charcoal (AC): It was purchased from Arab Drug Company in the form of tablets containing $100 \mathrm{mg}$ of $\mathrm{AC}$ which was grind and mixed with the ration.

Animals: The present study was conducted with 40 mature male albino rats of Wister strain, weighing $140-160 \mathrm{~g}$. The rats were purchased from the National Research Center and were allowed to acclimate to their new environment for 7 days prior to initiation of the experiment. Water and food were provided adlibitum.

Experimental design: The fourty male rats were divided into 4 groups (10 rats /group) during the experiment (63) days (the duration time of spermatgenesis), control rats (group I) received distilled water. Lead treated rats (group II, III and IV) received lead $(0.5 \mathrm{~g} / 100 \mathrm{ml})$ as lead acetate dissolved in distilled water according to (Jin et al., 2008). Casein or charcoal was mixed to the ration at a concentration of $20 \mathrm{~g} / 100 \mathrm{~g}$ 
ration and $0.05 \mathrm{~g} / 100 \mathrm{~g}$ ration, respectively according to Blanusa et al. (1989) and Cupic et al. (2003), respectively. The experimental design was showed in Table (1).

Table 1: Experimental design.

\begin{tabular}{|l|l|l|l|l|}
\hline Groups & Material & Concentration & Route of exposure & $\begin{array}{l}\text { Period of } \\
\text { experiment }\end{array}$ \\
\hline $\begin{array}{l}\text { Group (I) } \\
\text { control }\end{array}$ & $\begin{array}{l}\text { Distilled } \\
\text { water }\end{array}$ & - & - & \\
\cline { 1 - 4 } Group (II ) & Lead & $0.5 \mathrm{~g} / 100 \mathrm{ml}$ & via drinking water & \multirow{2}{*}{ For 63 days } \\
\cline { 1 - 4 } Group (III ) & $\begin{array}{l}\text { lead }+ \\
\text { Casein }\end{array}$ & $\begin{array}{l}0.5 \mathrm{~g} / 100 \mathrm{ml}+20 \\
\mathrm{~g} / 100 \mathrm{~g} \text { ration }\end{array}$ & $\begin{array}{l}\text { via drinking water+ } \\
\text { food intake }\end{array}$ & \\
\hline Group (IV ) & $\begin{array}{l}\text { Lead+ } \\
\text { Charcoal }\end{array}$ & $\begin{array}{l}0.5 \mathrm{~g} / 100 \mathrm{ml} 0.05 \\
\mathrm{~g} / 100 \mathrm{~g} \text { ration }\end{array}$ & $\begin{array}{l}\text { via drinking water+ } \\
\text { food intake }\end{array}$ & \\
\hline
\end{tabular}

Sampling: At the end of the experiment (63 days) blood samples were collected from the retro-orbital venous plexus of each rat. Blood samples were centrifugated at $3000 \mathrm{r}$.p.m for 15 minutes and separated serum samples were kept for left cloting in a deep freez at $-20^{\circ} \mathrm{C}$ until used for hormonal assay and immunological studies.

Pathological examination: The rats were sacrificed and dissected to remove testes, epididymis, prostate and seminal vesicles. They were grossly examined and accurately weighed. Tissue specimens from these organs were taken and fixed in $10 \%$ formol saline, processed by conventional paraffin embedding technique, sectioned (3-4 Mm) and stained by hematoxyline and eosin (Bancroft and Stevens, 1990) for routine histopathological examination.

Evaluation of semen quality: Spermatozoa were obtained by mincing the cauda epididymis in a known volume of physiological saline at $37^{\circ} \mathrm{C}$. The motility was evaluated directly after mincing. The spermatozoa were counted with haemocytometer and smears stained with eosin were made for determining the vitality\% and morphological characters of sperm according to (Krazanowska et al., 1995). Sperms head which were stained red with eosin were considered as dead sperms, while colourless sperms were known as live sperms. The percentage of live sperms was calculated by counting 100 sperm for each group. Nuclear maturation was evaluated by aniline blue stain and eosin (1: 1) according to the method described by Morel et al. (1998), sperm nuclei that stained blue were considered to be immature. 
Hormonal assays: Total testosterone $(\mathrm{T})$ was determined by radio immunoassay method as described by (Abraham, 1997) using kits (Coast - Acount) provided by Orion Diagnostic Spectria, Finland. FSH and LH were detennined by Eliza kits as described by Engvall, (1980).

\section{Immunological Studies:}

Determination of total antioxidant: They were assayed using colorimetric diagnostic kits (Bio -Diagnostic) according to Koracevic et al. (200 1).

Nitric oxide assay: $100 \mu \mathrm{l}$ of each serum sample was mixed with an equal volume of freshly prepared Greiss reagent $(0.5 \%$ sulfanilamide in $2.5 \%$ phosphoric acid and $0.05 \% \mathrm{~N}-1$-naphthy-1- ethylene diamine dihydrochloride) into flat -bottom 96 well ELISA plate at $210 \mathrm{C}$ for 10 minutes. Absorbency was measured at $570 \mathrm{~nm}$ using ELISA reader. The nitrite level in serum samples was calculated by comparing the optical density against the nitrite standard curve of sodium nitrite in distilled water as previously described by Green et al. (1982).

Measurment of lysozyme activity: Lysozyme was estimated according to Peeters and Vantrapen (1977). Briefly 25 III of each serum sample was added to wells cut in agarose gel (1\% in PBS) in which Micrococcus lysodeikticus cells $(50 \mathrm{mg} / 100 \mathrm{ml}$ agarose) had been dispersed. Plates poured with $4 \mathrm{~mm}$ depth. The diameter of clear zone formed around the wells after 24 hours was measured. The concentration of lzsozyme was obtained from logarithmic curve using standard lysozyme.

Malondialdehyde determination (MDA): MDA are assayed using colorimetric diagnostic kits (Bio diagnostic) following the manufacture's instructions according to Satoh (1972).

Kidney function tests: Urea test was determined according to Coulombe and Favreau (1963). Creatinin determination was done according to Heinegard and Tiderstrom (1976). Liver function tests: Alkaline phosphatase test (ALP) was detennined according to Douman et al. (1971), while gamma glotamyl transaminase (GGT) was determined by kinetic method according to Persijin and Slik (1976).

Electrophoretic pattern of serum protein: Serum protein fractions were separated according to Gordon (1980) using polyacrylamide gel electrophoresis, tris running buffer at volt 80 and stained by commassie brilliant blue R- 250 .

Statistical Analysis: The obtained data were statistically analysed using ANOV A test on a computer program (SPSS -14, 2006) and t- test according to Snedecor and Cochran (1980). 


\section{RESULTS}

Weights of sexual organs (testes, epididymis, prostate glands and seminal vesicles) exhibited a variable significant differences in all treated groups for 63 days comparing to control group (Gr I). Results of lead treated rats (Gr II) exhibited a highly significant decrease in the weights of all sexual organs comparing with control group (Gr I). Casein supplementation (Gr III) improved significantly sexual organs weight as compared to lead treated rats (Gr II), while charcoal supplementation (Gr IV) showed a moderate significant improvement, but still lower than casein treated group (Gr III), (Table 2).

Pathological examination: The histopathological findings of sexual organs of lead treated rats showed that testes revealed severe testicular degeneration represented by depletion of the spermatogonal cells (Fig. 1) and interstitial edema, in addtion inhibition of spermiogenesis was seen in most tubules. Few tubules showing moderate hypospermatocytogenesis (Fig. 2). Moreover, few tubules appeared necrosed and only remnants of the tubules were noticed. Epididymis showed no sperms in the lumina of most tubules. In addtion, lumina of some tubules contained cellular debris and spermatogonial cells (Fig. 3). Mild intertubular fibrous C.T. proliferation was also seen. Mild congestion was observed in prostate glands and seminal vesicles and mild intertubular fibrous C.T. proliferation and necrobiotic changes (the epithelium appeared vacuolated with pyknotic nuclei) in some of the glandular epithelium (Fig.4). The pathological changes were improved clearly in sexual organs of Casein supplementation (Gr III) and slight improvement in charcoal supplementation (Gr IV) as compared to lead treated rats (Gr II), which revealed compact seminiferous tubules with different stages of spermatogonial cells and the centers of the tubules contained great numbers of spermatids and spermatozoa (Fig. 5). In addition, lumina of the epididymal tubules showed large numbers of spermatozoa and some spermatids (Fig. 6).

Sperm parameters: No significant differences in all parameters of sperm quality determination in group III comparing with control (Gr I) except in sperm abnormality \% there was a little significance $(\mathrm{P}<0.001)$. The results showed no significant differences (azospermia) between $\mathrm{Gr}$ IV (lead + charcoal treated) and lead treated group (Gr II) (Table 3).

Serum hormones: Lead exposure throughout the experiment suppressed significantly the levels of serum testosterone in all treated groups comparing with control rats. Charcoal supplementation improved 
significantly the concentrations of serum FSH and LH comparing with lead treated rats (Gr II), while casein supplementation normalized their levels, (Table 4). These results revealed that casein treatment improved lead toxicity state meanwhile, charcoal supplementation showed less improvement.

Immunological studies: Our results showed that lead exposure (Gr II) throughout the experiment induced a significant reduction in total antioxidant production as compared to control group, while casein supplementation normalized its level. Comparing with control group there were a significant decrease in nitric oxide activity and lysozyme levels after lead treatment (group II). After casein supplementation the nitric oxide and lysozyme levels increased to reach control levels. Regarding to charcoal, there was slight improvement of the above mentioned parameters, but these results remain significant different compared to lead treated group (Gr II), (Table, 5). Regarding to the immunotoxicity induced by lead, it is clear that there was a significant increase in malondialdehyde after lead exposure as a result of lipid peroxidation as compared to control group. Casein treatment exhibited a significant decrease in malondialdehyde level as compared to lead treated group (Table, 6). Concerning to kidney function tests, lead induced a marked significant increase in serum levels of urea and creatinine comparing with control rats (Gr I). Lead exposure exhibited also a significant elevation in the concentration of alkaline phosphatase (ALP) and gamma glutamyl transferase (GOT) enzymes. By adding casein (Gr III) a marked significant decrease in the above mentioned data as recorded reaching to normal values of control (Gr I). Charcoal treated group exhibited a little improvement in the previous data comparing with lead intoxicated rats (Table, 6). Concerning to electrophoretic pattern of rat serum (Table, 7) there were significant decreases in total protein and albumin levels in Gr II (lead treated group) against control (Gr I ), while casein treatment normalized their levels. Regarding to $\alpha, \beta$ and $\gamma$ globulin, after casein treatment there was a significant improvement in their values to reach normal levels, but lead intoxication decreased levels of $\alpha$ and $\gamma$ significantly comparing to control group. Results of detoxification of lead by activated charcoal (Gr IV) revealed slight improvement in group IV as compared to lead intoxicated rats (Gr II), but the values did not reach the normal level of control (Gr I). 
Table 2: Weights of sexual organs of male rats exposed to lead, lead + casein or lead + charcoal for 63 days $(n=10)$.

\begin{tabular}{|l|l|l|l|l|l|}
\hline \multirow{2}{*}{ Groups } & \multirow{2}{*}{ Treated materials } & \multicolumn{4}{|l|}{ Weights of sexual organs g/100g b. wt. } \\
\cline { 3 - 6 } & & Testes & Epidydemis & Prostate & $\begin{array}{l}\text { Seminal } \\
\text { vesicles }\end{array}$ \\
\hline GrI(control) & - & 1.126 & 0.510 & 0.416 & 0.520 \\
& & $\pm 0.0533^{\mathrm{a}}$ & $\pm 0.032^{\mathrm{a}}$ & $\pm .010^{\mathrm{a}}$ & $\pm 0.11^{\mathrm{a}}$ \\
\hline GrII & Lead 0.5\% & 0.285 & 0.088 & 0.009 & 0.002 \\
& $\begin{array}{l}\text { Lead } \\
\text { GrIII }\end{array}$ & $\pm 0.5 \%+c a s 1^{\mathrm{d}}$ & $\pm 0.009^{\mathrm{d}}$ & $\pm 0.00^{\mathrm{d}}$ & $\pm 0.0002^{\mathrm{d}}$ \\
\hline GrIV & $\begin{array}{l}\text { Lead } 0.5 \%+ \\
\text { charcoal0.05\% }\end{array}$ & $\begin{array}{l}0.939 \\
\pm 0.029^{\mathrm{b}}\end{array}$ & $\begin{array}{l}0.420 \\
\pm 0.027^{\mathrm{b}}\end{array}$ & $\pm .007^{\mathrm{b}}$ & $\pm 0.013^{\mathrm{b}}$ \\
\hline
\end{tabular}

a, b, c, d insignificant difference between similar letters using Duncan multiple range test at $\mathrm{P}<0.05$ within the same raw.

Table 3: The semen picture of male rats exposed to lead, lead +casein or lead + charcoal for 63 days $(n=10)$.

\begin{tabular}{|l|l|l|l|l|l|l|}
\hline Groups & $\begin{array}{l}\text { Treated } \\
\text { materials }\end{array}$ & $\begin{array}{l}\text { Sperm cell } \\
\text { concentration } \\
\left(10^{6} / \mathrm{ml}\right)\end{array}$ & Motility $\%$ & Vitality \% & Maturity \% & Abnormality\% \\
\hline GrI(control) & - & $86.8 \pm 1.9$ & $89.0 \pm 1.3$ & $91.0 \pm 1.0$ & $91.0 \pm 0.8$ & $9.0 \pm 0.8$ \\
\hline GrII & Lead $0.5 \%$ & & \multicolumn{5}{|c|}{ Azospermia } \\
\hline GrIII & $\begin{array}{l}\text { Lead } 0.5 \%+ \\
\text { casein } 20 \%\end{array}$ & $83.5 \pm 2.01$ & $86.0 \pm 2.5$ & $85.0 \pm 2.0$ & $83.0 \pm 5.0$ & $16.0 \pm 1.1^{*}$ \\
\hline GrIV & $\begin{array}{l}\text { Lead } 0.5 \%+ \\
\text { charcoal } 0.05 \%\end{array}$ & \multicolumn{7}{|c|}{ Azospermia } \\
\hline
\end{tabular}

* Significant at $\mathrm{P}<0.001$ comparing with control using t-student test. 
Table 4: Serum testosterone, FSH and LH levels of male rats exposed to lead, 1ead +casein or lead + charcoal for 63 days $(n=I 0)$.

\begin{tabular}{|l|l|l|l|l|}
\hline Groups & Treated materials & Testosterone $(\mathrm{ng} / \mathrm{ml})$ & $\begin{array}{l}\text { FSH } \\
(\mathrm{mlu} / \mathrm{ml})\end{array}$ & $\begin{array}{l}\text { LH } \\
(\mathrm{mlu} / \mathrm{ml})\end{array}$ \\
\hline GrI(control) & - & $1.88 \pm 0.103 \mathrm{a}$ & $3.55 \pm 0.025 \mathrm{a}$ & $2.61 \pm 0.075 \mathrm{a}$ \\
\hline GrII & Lead $0.5 \%$ & $1.02 \pm 0.079 \mathrm{~b}$ & $1.4 \pm 0.047 \mathrm{c}$ & $1.61 \pm 0.099 \mathrm{c}$ \\
\hline GrIII & $\begin{array}{l}\text { Lead } 0.5 \%+\text { casein } \\
20 \%\end{array}$ & $1.14 \pm 0.075 \mathrm{~b}$ & $3.4 \pm 0.188 \mathrm{a}$ & $2.4 \pm 0.140 \mathrm{a}$ \\
\hline GrIV & $\begin{array}{l}\text { Lead } 0.5 \%+ \\
\text { charcoal0.05\% }\end{array}$ & $1.12 \pm 0.066 \mathrm{~b}$ & $2.1 \pm 0.149 \mathrm{~b}$ & $1.85 \pm 0.042 \mathrm{~b}$ \\
\hline
\end{tabular}

$\mathrm{a}, \mathrm{b}, \mathrm{c}$, insignificant difference between similar letters using Duncan multiple range test at $\mathrm{P}<0.05$ within the same raw using ANOVA test.

Table 5: Immunosecretory molecules: Total antioxidant, nitric oxide. and lysozyme in serum of rats exposed to lead, lead +casein or lead + charcoal for 63 day $(n=10)$.

\begin{tabular}{|c|c|c|c|c|}
\hline \multirow[b]{2}{*}{ Groups } & \multirow[b]{2}{*}{ Treated materials } & \multicolumn{3}{|c|}{ Parameters } \\
\hline & & $\begin{array}{c}\text { Total } \\
\text { Antioxidant } \\
(\mathrm{mM} / \mathrm{L})\end{array}$ & $\begin{array}{l}\text { Nitric oxide } \\
\text { umol/ul }\end{array}$ & $\begin{array}{l}\text { lysozyme } \\
\mathrm{ug} / \mathrm{ml}\end{array}$ \\
\hline GrI(control) & - & $1.19 \pm 0.005 \mathrm{a}$ & $22.99 \pm 0.065 \mathrm{a}$ & $155.74 \pm 0.150 \mathrm{a}$ \\
\hline GrII & Lead $0.5 \%$ & $0.71 \pm 0.008 \mathrm{c}$ & $14.25 \pm 0.15 \mathrm{c}$ & $131.46 \pm 0.961 \mathrm{c}$ \\
\hline GrIII & $\begin{array}{l}\text { Lead } \\
0.5 \%+\text { casein } 20 \%\end{array}$ & $1.13 \pm 0.017 \mathrm{a}$ & $22.50 \pm 0.278 \mathrm{a}$ & $154.29 \pm 0.196 a$ \\
\hline GrIV & $\begin{array}{l}\text { Lead } 0.5 \%+ \\
\text { charcoal } 0.05 \%\end{array}$ & $0.87 \pm 0.034 b$ & $18.91 \pm 0.130 b$ & $139.21 \pm 2.598 b$ \\
\hline
\end{tabular}

The result of each group represented by (mean of ten rats \pm SE)

$\mathrm{a}, \mathrm{b}, \mathrm{c}$, insignificant difference between similar letters using Duncan multiple range test at $\mathrm{P}<0.05$ within the same raw using ANOV A test. 
Table 6: Malondialdehyde concentration and some biochemical parameters in serum of rats exposed to lead, lead +casein or lead + charcoal for 63 days $(n=10)$.

\begin{tabular}{|l|l|l|l|l|l|l|}
\hline Groups & $\begin{array}{l}\text { Treated } \\
\text { Materials }\end{array}$ & $\begin{array}{l}\text { Malondiald } \\
\text { ehyde } \\
\text { concentration } \\
(\mathrm{nmol} / \mathrm{ml})\end{array}$ & $\begin{array}{l}\text { Urea } \\
(\mathrm{mg} / \mathrm{dl})\end{array}$ & $\begin{array}{l}\text { Creatinin } \\
(\mathrm{mg} / \mathrm{dl})\end{array}$ & Alp(U/L) & GGT(U/L) \\
\hline $\begin{array}{l}\text { GrI } \\
\text { (control) }\end{array}$ & - & $1.84 \pm 0.017 \mathrm{a}$ & $31.17 \pm 0.065 \mathrm{a}$ & $0.56 \pm 0.016 \mathrm{a}$ & $21.14 \pm 0.191 \mathrm{a}$ & $4.50 \pm 0.015 \mathrm{a}$ \\
\hline GrII & Lead $0.5 \%$ & $3.57 \pm 0.188 \mathrm{c}$ & $59.41 \pm 0.317 \mathrm{c}$ & $1.90 \pm 0.008 \mathrm{c}$ & $50.20 \pm 2.587 \mathrm{c}$ & $7.10 \pm 0.187 \mathrm{c}$ \\
\hline GrIII & $\begin{array}{l}\text { Lead } \\
0.5 \%+\text { casein } \\
20 \%\end{array}$ & $1.78 \pm 0.025 \mathrm{a}$ & $30.74 \pm 0.303 \mathrm{a}$ & $0.61 \pm 0.007 \mathrm{a}$ & $20.26 \pm 0.206 \mathrm{a}$ & $4.48 \pm 0.021 \mathrm{a}$ \\
\hline GrIV & $\begin{array}{l}\text { Lead } 0.5 \%+ \\
\text { charcoal } 0.05 \%\end{array}$ & $0.46 \pm 0.242 \mathrm{~b}$ & $37.74 \pm 0.918 \mathrm{~b}$ & $1.39 \pm 0.185 \mathrm{~b}$ & $29.98 \pm 0.859 \mathrm{~b}$ & $6.62 \pm 0.171 \mathrm{~b}$ \\
\hline
\end{tabular}

ALP: Alkaline phosphatase activity

GGT: Gamma glutamyl transferase

The result of each group represented by (mean of ten rats \pm SE)

a, b, c, insignificant difference between similar letters using Duncan multiple range test at $\mathrm{P}<0.05$ within the same raw using ANOVA test.

Table 7: Immunoelectrophoretic pattern of total protein $(\mathrm{g} / \mathrm{dl})$ in serum of rats exposed to lead, lead +casein or lead + charcoal for 63 days $(\mathrm{n}=\mathrm{I} 0)$.

\begin{tabular}{|c|c|c|c|c|c|c|c|c|}
\hline \multirow[b]{2}{*}{ Groups } & \multirow[b]{2}{*}{$\begin{array}{l}\text { Treated } \\
\text { materials }\end{array}$} & \multicolumn{7}{|c|}{ Parameters } \\
\hline & & Total protein & Albumin & $\begin{array}{l}\text { Total } \\
\text { globulin }\end{array}$ & $\alpha$ & $\beta$ & $\Gamma$ & $\mathrm{A} / \mathrm{G}$ ratio \\
\hline $\begin{array}{l}\text { GrI } \\
\text { (control) }\end{array}$ & - & $\begin{array}{c}4.99 \pm 0.159 \\
\text { A }\end{array}$ & $\begin{array}{c}2.87 \pm 0.062 \\
\mathrm{~A}\end{array}$ & $2.12 \pm 0.056$ & $\begin{array}{c}0.59 \pm 0.034 \\
\mathrm{a}\end{array}$ & $\begin{array}{c}0.61 \pm 0.013 \\
\text { B }\end{array}$ & $\begin{array}{c}0.92 \pm 0.093 \\
\mathrm{a}\end{array}$ & $1.35 \pm 0.04$ \\
\hline GrII & Lead $0.5 \%$ & $\begin{array}{c}4.31 \pm 0.128 \\
\text { B }\end{array}$ & $\begin{array}{c}2.30 \pm 0.048 \\
\mathrm{C}\end{array}$ & $1.83 \pm 0.09$ & $\begin{array}{c}0.40 \pm 0.018 \\
\mathrm{c}\end{array}$ & $\begin{array}{c}0.81 \pm 0.021 \\
\mathrm{~A}\end{array}$ & $\begin{array}{c}0.62 \pm 0.069 \\
b\end{array}$ & $1.25 \pm 0.044$ \\
\hline GrIII & $\begin{array}{l}\text { Lead } \\
0.5 \%+\text { case } \\
\text { in } 20 \%\end{array}$ & $\begin{array}{c}4.88 \pm 0.111 \\
\mathrm{~A}\end{array}$ & $\begin{array}{c}2.83 \pm 0.028 \\
\text { A }\end{array}$ & $2.05 \pm 0.13$ & $\begin{array}{c}0.55 \pm 0.019 a \\
\mathrm{~b}\end{array}$ & $\begin{array}{c}0.60 \pm 0.017 \\
\text { B }\end{array}$ & $\begin{array}{c}0.90 \pm 0.022 \\
\mathrm{a}\end{array}$ & $1.37 \pm 0.085$ \\
\hline GrIV & $\begin{array}{l}\text { Lead } 0.5 \%+ \\
\text { charcoal } \\
0.05 \%\end{array}$ & $\begin{array}{c}4.31 \pm 0.12 \\
\text { B }\end{array}$ & $\begin{array}{c}2.50 \pm 0.10 \\
\text { B }\end{array}$ & $1.81 \pm 0.19$ & $\begin{array}{c}0.51 \pm 0.012 \\
\mathrm{~b}\end{array}$ & $\begin{array}{c}0.51 \pm 0.021 \\
\mathrm{C}\end{array}$ & $\begin{array}{c}0.79 \pm 0.026 a \\
b\end{array}$ & $1.38 \pm 0.064$ \\
\hline
\end{tabular}

a, b, c, insignificant difference between similar letters using Duncan multiple range test at $\mathrm{P}<0.05$ Within the same raw using ANOVA test. 


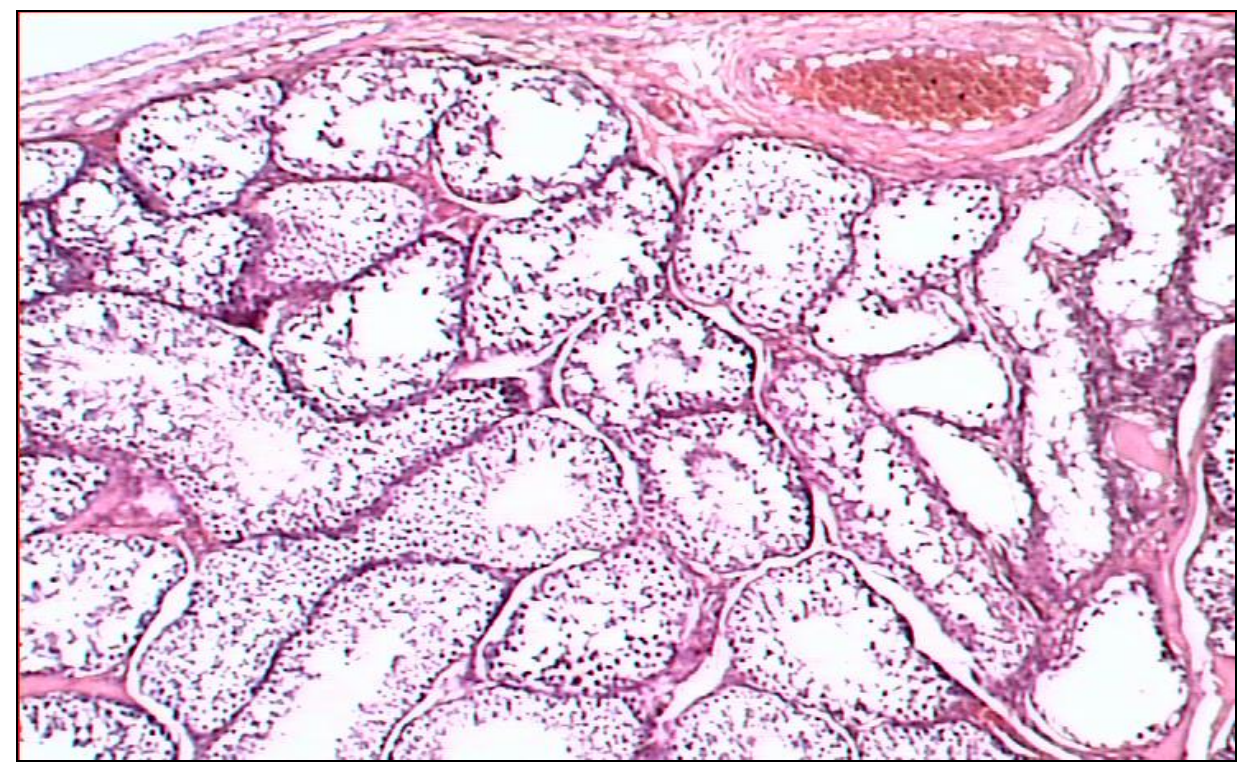

Fig. 1: Testis of lead treated rat showing depletion of the spermatogonial cells (some seminiferous tubules appeared with one or two layers of spermatogonia) (H\&E; X40).

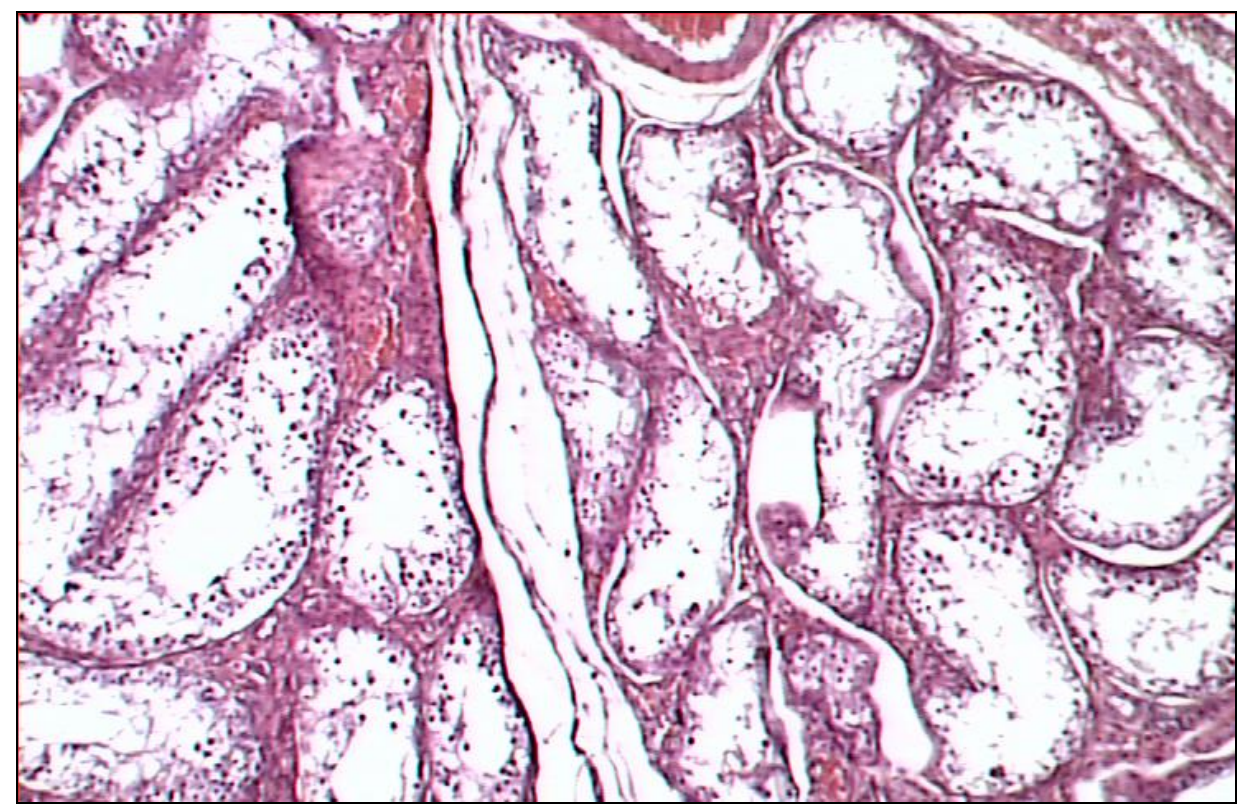

Fig. 2: Testis of lead treated rat showing moderate hypospermatocytogenesis, thickening of the basement membrane and inhibition of the spermiogenesis (H\&E; X40). 


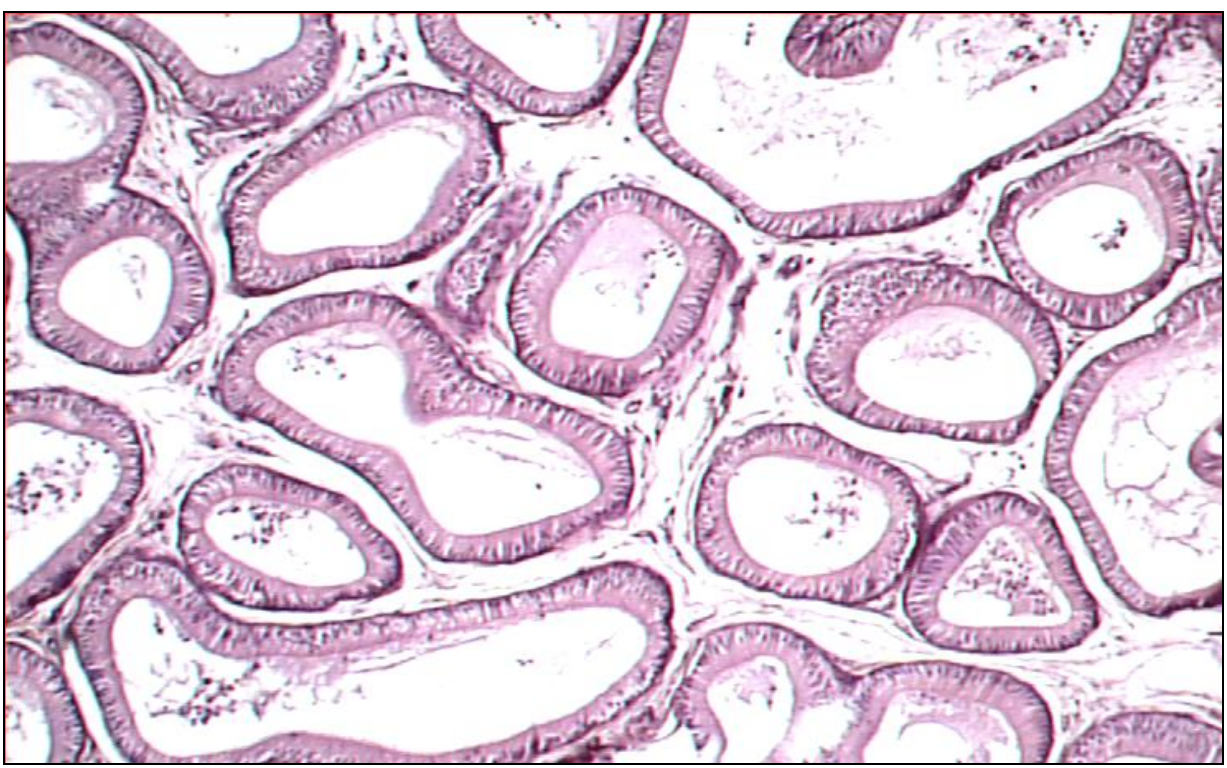

Fig. 3: Epididymis of lead treated rat showing no sperms in the lumina of most tubules and some tubules contained cellular debris and spermatogonial cells (H\&E; 40).

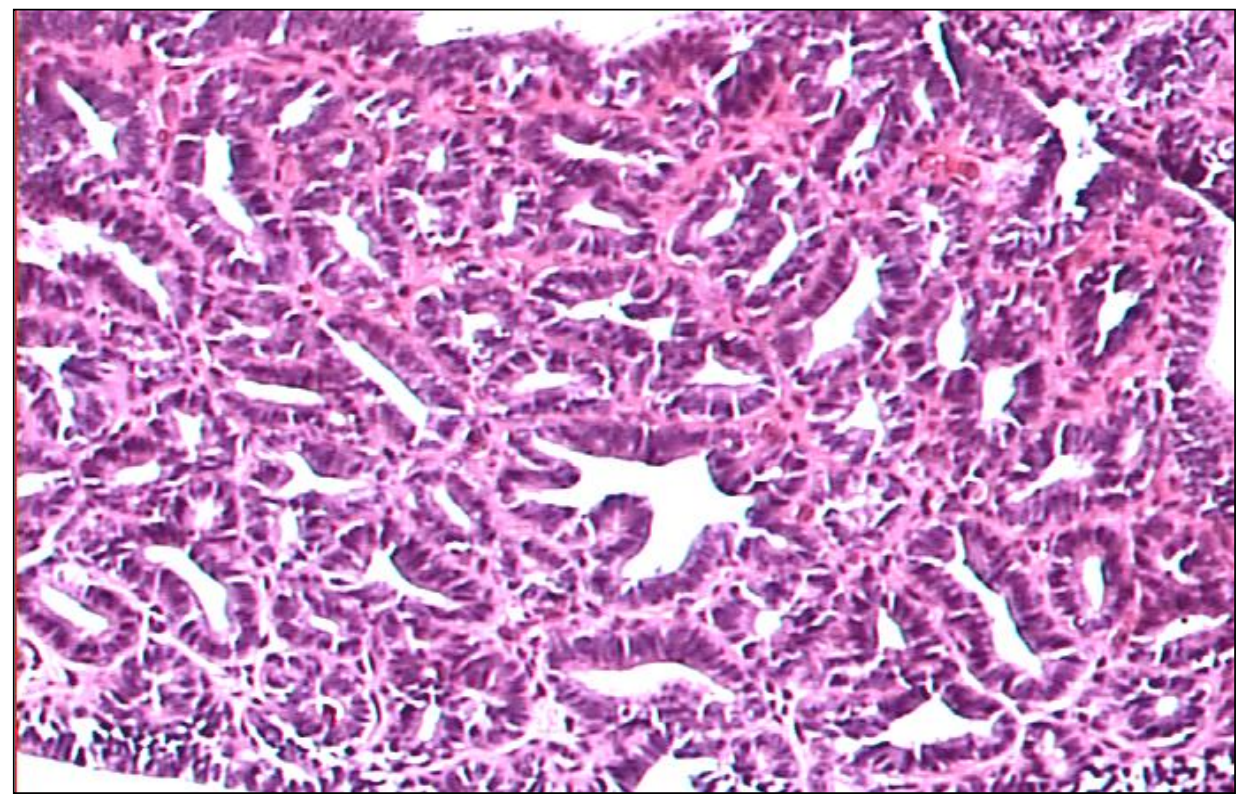

Fig. 4: Prostate gland of lead treated rat showing mild to moderate periglandular fibrous C.T. proliferation and degenerative changes in some of the glandular epithelium (H\&E; X 40). 


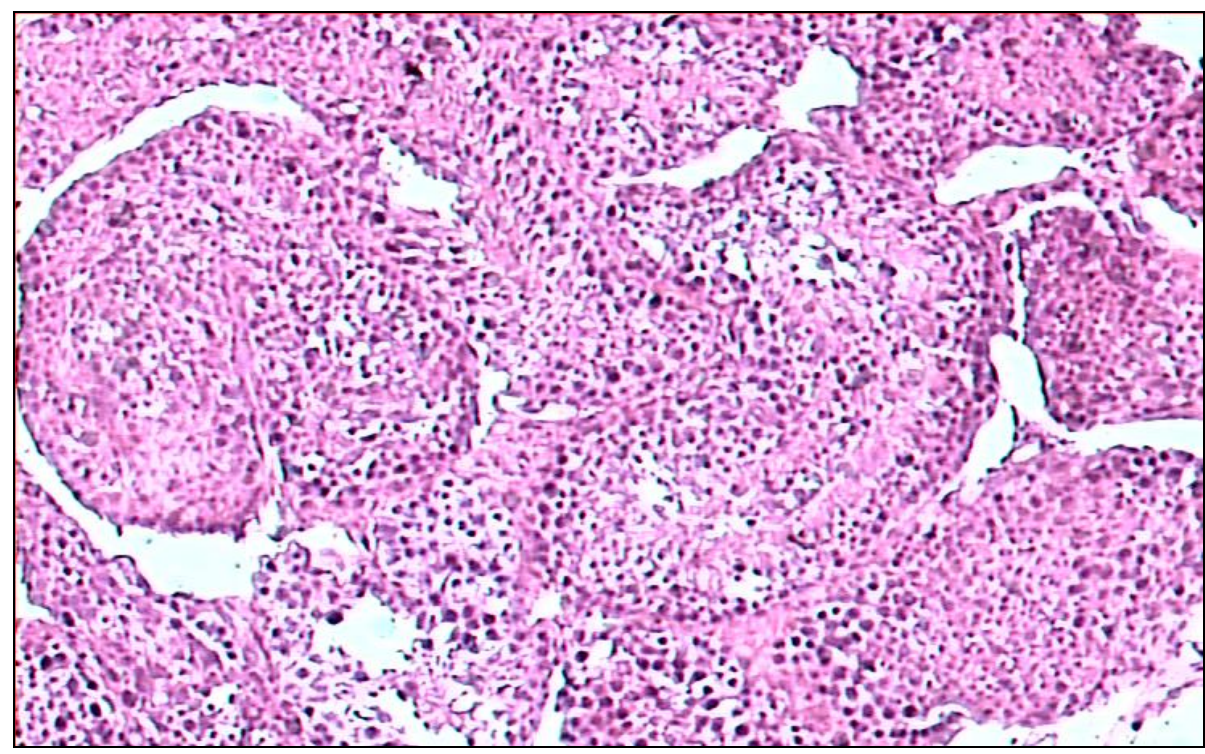

Fig. 5: Testis of casein treated rat showing compact seminiferous tubules with different stages of spermatogonial cells and the centers of the tubules contained great numbers of spermatids and spermatozoa (H\&E; X100).

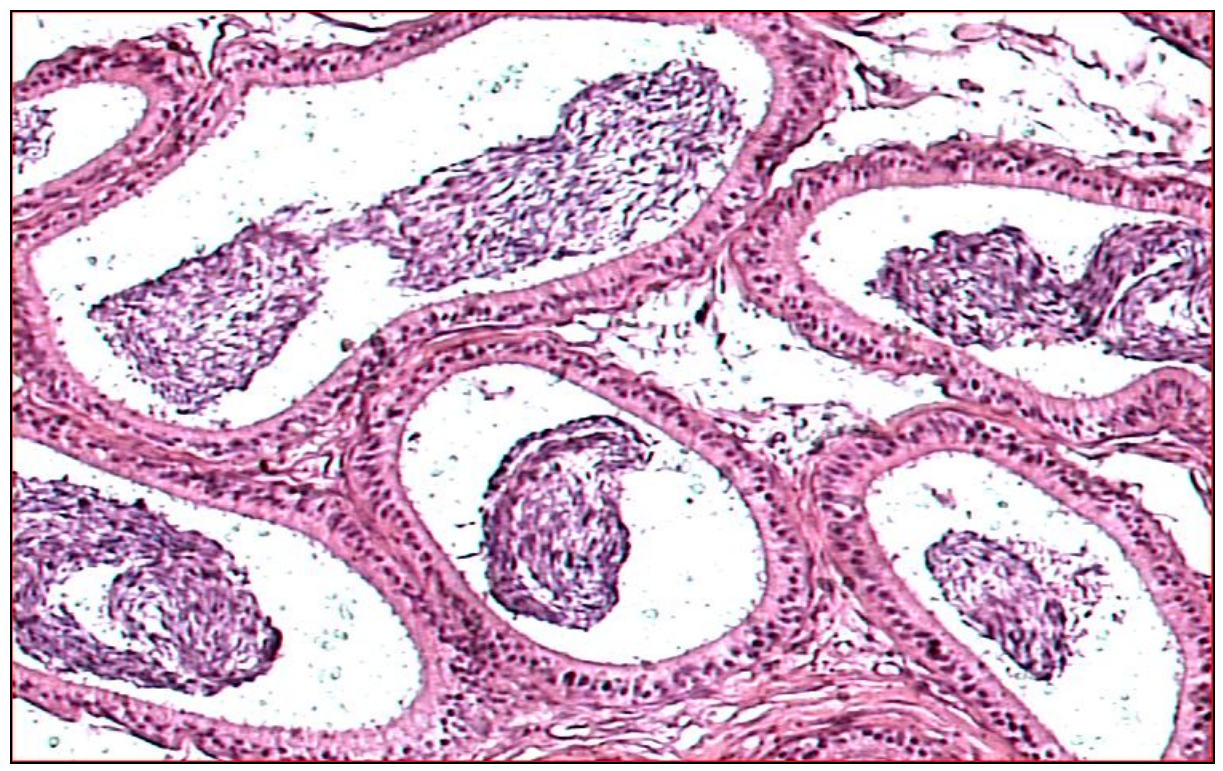

Fig. 6: Epididymis of casein treated rat showing large numbers of spermatozoa and some spermatids in the lumina of the tubules (H\&E; X100). 


\section{DISCUSSION}

Lead poisoning is a world wide health problem and its treatment is under investigation. Our study is concerned with investigation of the toxic effects of male sexual organs, serum sex hormone concentrations, sperm parameters as well as anti-oxidant production. In addition to, macrophage activity, malondialdehyde production, liver and kidney function tests and electrophoretic pattern of total protein in serum of male rats. Moreover, comparison of casein and charcoal supplementation for prevention of lead toxicity which is the main target of our study was discussed. Our study demonstrated that lead intoxication (Gr II) induced a highly significant reduction in size and weight of all sexual organs (testes, epidydmis, seminal vesicles and prostate glands). Testicular size and weight are normally regulated by fluid secretion from sertoli cells and the production of sperms in the seminephrous tubules (Waites and Oladwell, 1982). The pathological changes showed degenerative changes of germinal cells and sertoli cells of the testes and epididymis tubules in lead treated rats which lead to atrophied testes which reported previously by Bataineh et al. (1998); Batra et al. (2001) and (2004). These pathological changes were improved in Casein supplementation (Gr III) and charcoal supplementation (Gr IV) but the improvement in charcoal supplementation (Gr IV) was lower than casein treated group (Gr III), Moreover, Batra et al. (2001) observed reduction in the activity of two major enzymes in the testes, alkaline phosphatase and Na-KA TPase in lead exposed animals which may be another probable mechanism of lead induced degeneration of testes. In our study, completel arrest of spematogenesis was found in lead- treated rats (Gr II) and lead + charcoal treated group (azospermia). This was explained completely degeneration of spermatogonia and primary spermatocytes (Boscole et al., 1988). In the same manner previous studies showed a significant reduction in the sperm count, decreased spenn density and a high rate of teratozoospermia in rats (Hu et al., 1992; Lerda, 1992; Robins et al., 1997 and Danial et al., 2006). Further more Acharya et al. (2003) recorded that most of the testicular germ cells might have been destroyed after lead exposure either due to membrane damage or macromolecular degradation incurred by reactive oxygen radicals (ROS) leading to a significant decline in sperm count and ultimately testicular weight loss. Moreover, available literature during the recent past has revealed the causation of gene mutation induced by ROS generated by metals (Reid et al., 1994). On the contrary, testicular germ cells carrying 
minor gene mutation was not eliminated but are manifested as morphologically deformed sperm. It was also documented that certain chemicals including lead acetate, were germ cell mutagens affecting specific gene loci in spermatogonial cells, there by increasing the percentage of sperm abnormality (Soares et al., 1979). Hence. formation of abnormal spenn population in the present study (GrIII) may be likely due to mutagenic effects of lead -induced ROS on specific gene loci of germ cell chromosomes involved in the maintenance of normal sperm structure. The present study is in agreement with the recent finding of Hsu et al. (1998). Our results investigated that chronic administration of lead to normal mature male rats (Gr II) reduced the serum levels of FSH, $\mathrm{L} \mathrm{H}$ and testosterone hormones which in turn resulted in inhibition of testicular activity and the fall in accessory sexual organ weights (Bataineh et al., 1998 and Biswas and Ghosh, 2004). Testicular function was inhibited which was manifested by suppressed spermatogenesis and decreased serum testosterone level (Sokol et al., 1985). In the present study decreased circulating levels of FSH, LH and testosterone suggested a dual site of lead action: at the level of hypothalamic pituitary unit or directly at the level of gonadal steroid biosynthesis (Hypothalamic - pituitary -testicular axis) (Sokol, 1987; Ng, et al., 1991; Kempinas, et al., 1994 and Martin et al., 1996). Regarding to the immunotoxicity of lead, it is clear that lead induced destruction of total antioxidants in serum. This has been confirmed by Hsu and Guo (2002) as they stated that lead poisoning disturbed antioxidants that exist within the mammalian cells. The inhibition of antioxidant enzymes plays an important role in lead poisoning as antioxidant helps to reduce the oxidizing effect of pollutants and they are important in scavenging free oxygen radicals, stabilizing the cell membrane and its permeability (Mateo et al., 2003). Regarding to activity of macrophages it is clear that lead destroyed macrophage functions including decrease production of nitric oxide and lysozyme as previously recorded by Concerning to our results of serum nitric oxide and lysozyme levels; there was a decrease in nitric oxide in lead treated group as compared to control rats. This might be attributed to immunosuppression of lead poisoning, where lead was toxic to macrophages with depression of nitric oxide production (Krocova et al., 2000 and Lee et al., 2002). Our results also illustrated that there was a reduction in lysozyme activity after chronic lead toxicity as compared to control group. Lead toxicity induced suppression of cell mediated response (Miller et al., 1998) with destruction of macrophages (Bunn et al., 2000). Immunotoxicity induced by lead resulted in lipid 
peroxidation with increasing malondialdehyde production in lead intoxicated rats. The adverse effects of lead $(\mathrm{Pb})$ may be associated with oxidative damage of lipids, proteins and DNA. Moreover, inhibition of antioxidant enzymes plays an important role in lead poisoning due to increase lipid peroxidation (Mateo et al., 2003). Our studies illustrated the immunotoxicity of lead on both kidney and liver as induced by increased enzymatic activity. Lead is a cumulative poison on kidney and liver (Lokith, 1993). Our data revealed that there were hypoproteinemia, albuminaemia and decrease in A / G ratio due to lead toxicity on liver resulting from impaired synthesis of protein and albumin as recorded by Blood et al. (1993). Review of literatures revealed few studies about the effect of. Casein treatment on lead toxicity in male reproductive system and immunological state. In our study after 63 days casein supplementation (Gr III) showed no or little differences compared to control group (Gr I) in the most of our data (sperm parameters, hormonal concentrations, antioxidant values, nitric oxide lysozyme, malondialdehyde levels, kidney and liver enzymatic activity, total protein, albumin and gamma globulin. Previously, another researcher suggested that a possible relationship had been observed between susceptibility to lead toxicity and dietary content of protein. Millar et al. (1970) and Springer (2005) found that rats fed a protein free diet retain twice as much lead as rats fed a $20 \%$ casein diet. Saxena et al. (1989) demonstrated that higher percentage of lead, altered the enzyme levels inducing testicular degeneration to a greater extent in low protein fed rats compared to lead treated rats fed normal protein diet. In the same manner Hallen et al. (1996) recorded, that lead is excreted into the milk bound to casein. The mechanism by which lead bond to casein was explained by Srinivas et al. (2007) he recorded that the protein (casein) combines with lead ions and minimizes its absorption by cross -linking free, amino group and carboxylate group forming a precipitate. More oldest record from Baernstein and Grand (1942) stated that $20 \%$ casein in the diet protected rats from lead chloride (1.5\%) wheather the protective action of casein comes from reducing lead absorption or some other mechanism such as forming a less toxic, 1ead- protein complex. On the other hand it obviously clear from our data that activated charcoal (AC) fail to alleviate toxicity of lead in (Gr IV). Since this group (rats treated with lead and charcoal) showed highly significant differences compared to control group in most data as well as no alteration in sperm parameters (azospermia) between charcoal supplemented group and lead treated rats. These results were explained 
by Edrington, et al. (1996) as they suggested that the efficiency of toxin binding activity considerably varies depending on the chemical structure of both the adsorbent and the toxin, exposure condition $(\mathrm{pH}$, .temperature) and duration of exposure. So that, this contradiction could be attributed to the dose of both toxin and adsorbent (AC) or nature of the toxin. In conclusion the results of our study suggested that casein supplementation can minimize the toxic effects of lead on male reproductive and immune systems, so that we advise animal's breeders to mix adequate percentages of casein in ration to minimize lead toxicity. Regarding to AC, our results suggested the need for addition studies to learn about factors which regulate effectiveness of AC on lead toxicity.

\section{REFERENCE}

Abraham, G.E. (1997): Hand book of Radio Immunoassay. Marcel Dekker.

Acharya, U.R.; Acharya, S. and Mishra, M. (2003): Lead acetate induced cytotoxicity in Male Germinal cells of Swiss mice. Industrial Health; 41: 291-294.

Ademoyero, A. and Dalvi, R.R. (1983): Efficacy of activated charcoal and other agents in the reduction of heptotoxic effects of a single dose of aflatoxin $\mathrm{B}$, in chickens. Toxicology letters; volume 16 (Issue 1 and 2): 153-157.

Adhikari, N.; Sinha, N.; Narayen, R. and Saxena, D.K. (2001): Leadinduced cell death in testes of young rats. J. Applied. Toxicol.; 21: 275-277.

Alloway, B.L. (1990): Heavy metals in soils. New York, John Wily Inc.

Baernstein, H.D. and Grand, J.A. (1942): The relatiQn of protein intake to lead poisoning in rats. J. Phatmacol. Exp. Ther.; 74: 18.

Bancroft, J.D. and Stevens, A. (1990): Theory and Practice of Histopathological Techniques. Third edition, New York.

Bataineh, H.; Hamood, M. and Elbetieha, A.M. (1998): Assessment of aggression sexual behaviour and fertility in adult male rat following. long, term ingestion four industrial metals salts. Human and Experimental Toxicology; Vol. 17(10 S): 70-576.

Batra, N.; Nehru, B. and Bansal, M.P. (2001): Influence of lead and zinc on rat male reproduction at biochemical and histopathological levels. J. Appl. Toxicol.; 21: 507-12. 
Batra, N.; Nehru, B. and Bansal, M.P. (2004): Reproductive potential of male porten rats exposed to various levels of lead with regard to zinc: status. Br. J. Nuts.; 91: 1887-1891.

Biswas, N.M. and Ghosh, P.K. (2004): Effect of gold on testicular steroidogenic and gametogenic function in immature male albino rats. Life Sci.; in press.

Blanusa, M.; Piasek, M. and Kostial, K. (1989): Interaction of lead with; some essential elements in rat's kidney in relation to age. BioI. Trace Elem. Res.; 21: 189-93.

Blood, D.; Radostits, O. and Hendersons, J. (1993): Veterinary Medicine I 6th edition, Williams and Wilking Co., Blatimore, Baillier, Trindall, I IUSA.

Boscolo, P.; Carmignahi, M.; Sacchettoni -logroscino, G.; Ranelletti, F.O.; Artese, L. and Preziosi, P. (1988): Ultrastructure of the testis in! rats with blood hypertension induced by long term lead exposure. Toxicol. Lett.; 41: 129-137.

Bunn, T.L.; Marsh, J.A. and Dietert, R.R. (2000): Gender difference in developmental immunotoxicity to lead in the chicken. J. Toxicol. Environ. Health; 61(8): 677-93.

Coulombe, J.J. and Favreau, L. (1963): New simple semi micro method for colori- metric determination of urea. Clin. Chem.; 9: 102-108. -327

Cupic, V.; Dobric, S.; Milovanov.ic, Z. and Bokonjic (2003): The efficacy of activated charcoal and klinoptiolite in protection of animals poisoned by bromadiolone. Toxic. Let. Vol. 144, P. 175.

Danial, R.; Gholamreza, R. and Mohammed, J.G. (2006): Morphometic changes of rat testis after subchronic oral lead intoxication and D- penicillamine treatment. Pakistan Journal of biological science; 9 (7): 1310-1314.

De Francisco, W.; Ruiz Troya, J.D. and Aguera, E.L. (2003): Lead and lead toxicity in domestic and free living birds. Avian Pathol.; 32(1): 3-13.

Der, R.; Hilderbrand, D.; Fahim, Z.; Griffin, W.T. and Fahim, M.S. (1974): In "Trace substances in environmental health". Vlll, ed. D.D. Hemphill, pp 417-431. Columbia: Univ. of Missouri Press.

Douman, B.T.; Watson, W.A. and Biggs, H.G. (1971): A colorimetric method for determination of serum albumin. Clin. Chem. Acta; 31: 87. 
Edrington, T.S.; Sarr, A.B.; Kubena, L.E.; Harvery, R.B. and Philips, T.D. (1996): Effects of hydrated sodium calcium alumiosilica (HSCAS), acidic HSCAS and activated charcoal on metabolic profile and toxicity of aflatoxine BI in turkey poults. Toxic. Let.; 89: 115-122.

Ellenhorn (1997): Medical Toxicology 2nd ed. William and Wilkins.

Engvall (1980): Methods in enzymology, Vol. 70. Van Vunakis, H. and, langone, J.J. Academic press, New York, 419.

Fatma, M. Fakhry (1992): Teratogenecity and placental transfer study of lead in relation to LD50 in albino rats. The new Egyption J. of Medicine; Vol. 7 No ( 6): 1220-1229.

Gidlow, D.A. (2004): Lead toxicity. Occup. Med. (Lond.); 54: 76-81.

Golubovich, E.; Aukimenko, M.M. and Chirkova. E.M. (1968): Toksik, Khim. Veshchestv; 10-64.

Gontzeer, I.; Gutzesco, P.; Corona, D. and Lungu, D. (1964): Lead toxicity. Arch. Sci. Physiol. (Paris); 18: 211-224.

Gordon, A.H. (1980): Electrophoresis of protein in polyacrylamide and starch gels. In Laboratory Techniques in Biochemistry and Molecular Biology. El-Seivernorth Holland Biochemical Press, Amsterdam, P. 213.

Goyer, R.A. and Mehman, M.A. (1977): Toxicology of Trace Elements: In, Nutrient Interactions with Toxic Elements. Eds. Goyer, R. A. and Mehhnan, M.A. Hallsted Press, New York, pp 245.

Green, L.C.; Awagner, D.A.; Glogowshi, J.; Skipper, P.L.; Wishok, J.S. and Tannebaum, S.R. (1982): Analysis of nitrate, nitrite and $(15 \mathrm{~N})$ nitrite in biological fluids. Anal. Bioch.; 126: 131-138.

Hallen, I.P.; Norrgren, L. and Oskarron, A. (1996): Distribution of lead in lactating mice and suckling off spring with special emphasis on the mammary gland. Arch. Toxicol.; 70 (3-4): 237-43.

Heinegard, J. and Tideratrom, K. (1976): Determination of serum creatinine by colorimetric- method. Clin. Chem. Acta; 43: 305310.

Hsu, P.C.; Lo, M.Y.; HSU, C.C.; Chen, L.Y. and Goo, Y.L. (1998): Effects of Vit. E and / or C or reactive oxygen species -related lead toxicity in rat sperm. Toxicology; 128: 169-79.

Hso, P.C. and Guo, Y.L. (2002): Antioxidant nutrients and lead toxicity Toxicology; 180 (1): 33-44. 
Hu, W.Y.; Wang, L.L. and Hovatta, O. (1992): A toxicological and epidemiological study on reproductive functions of male workers exposed to lead. J. Hyg. Epidemiol. Microbial. Immunol.; 36: 25-30.

Jin, C.; Li, Y.; Li, Y.L.; Zoo, Y.; Zhang, G.L.; Normora, M. and Zho, G.Y. (2008): Blood lead: Its effect on trace element levels and iron "' structure in hemoglobin. Nucl. Instr. And Meth. In Phys. Res.; B 206: 3607-3613.

Jindal, N.; Mahipal, S.K. and Mahajan, N.K. (1994): Toxicity of aflatoxin BI in broiler chicks and its reduction by activated charcoal. Res. Vet. Sci.; 56(1): 37-40.

Kempinas, W.G.; Favaretto, AT.V. and Melo, V.R. (1994): Timedependent effects of lead on rat reproductive functions. .T. Appl. Toxicol.; (14): 427-433.

Khanna, R. and Johri, G.N. (1991): Lead and immunity suppression of humoral immune response to hymenolepis nana in mice. $\mathrm{J}$. Hyg. Epidemiol. Microbiol. Immunol.; 35(1): 1-7.

Koracevic, D. and Koracevic, G. (2001): Clin. Pathol.; (54): 356-361.

Krazanowska, H.; Styrna, J. and Wabiksil, B. (1995): Analysis of sperm quality in recombinant in bred mouse strain. J. Report. Fertil.; (104): 347-354.

Krocova, Z.; Macela, A.; Kroca, M. and Hernychova, L. (2000): The immunomodulatory effects of lead and cadmium on the cells of immune system in vitro. Toxicol. In Vitro; 14 (1): 33-40.

Lancranjan, I.; Popesca, H.I.; Gavanesca, 0.; Klepsch, I. and Serbanese, M. (1975): Reproductive ability of workmen/ occupationally exposed to lead. Arch. Environ. Health; 30(8): 396-401.

Lee, J.E.; Naqi, S.A.; Kao, E.; Dietert, R.R. (2002): Embryonic exposure to lead: comparison of immune and cellular responses in unchallenged and virally stressed chickens. Arch. Toxicol.; 75(12): 717-24.

Lerda, D. (1992): Study of spenn characteristics in persons occupationally exposed to lead. Am. J. Ind. Med.; 22: 567-571.

Lokith, G. (1993): Perspectives on lead toxicity. Clin. Biochem.; 26: 371-381.

Martin, J.; Ronis, J.; Thomas M.B.; Sarah, J.S.; Paulak, R. and Fatima, Sh. (1996): Reproductive toxicity and growth effects in rats exposed to lead at different periods during development. Toxicology and applied pharmacology; V. 136 (2): 361-371. 
Mateo, R.; Beyer, W.N.; Spann, J.W.; Hoffman, D.J. and Ramis, A.I. (2003): Relationship between oxidative stress, pathology, and I behavioral signs of lead poisoning mallards. J. Toxicol. Environ. I Health; 66(14): 1371.

Millar, J.A.; Battistini, V.; Cumming, R.L.C.; Carswell, F. and Goldberg, A. (1970): Effect of lead on mammalian reproduction. Lancet; 2: 695.

Miller, T.E.; Golemboski, K.A.; Ha, R.S.; Bonn, T.; Sanders, F.S. and Dietert, R.R. (1998): Developmental exposure to lead causes er:istent immunotoxcity in fischer 344 rats. Toxicol. Sci.; 42 (2): 129-3.

Morel, B.S.; Mercier, S.; El Mirini, T.; Clavequin, M.C. and Bresson, J.L. (1998): Inter individual variations in the dismoy frequencies of human spermatozoa and their correlation with nuclear maturity as evaluated by aniline blue staining. Fertile. Steril.: 69: 112-1127.

Murthy, R.C. (1991): Lead induced ultrastructllral cllanges in the testes of, rats. Exp. Path.; 42: 95-100.

Ng, T.P.; Gob, H.H. and Ong, H.Y. (1991): Male endocrine functions in - workers with moderate lead exposure. Br. J. Ind. Med.; 48: 485-491.

Peeters, T.L. and Vantrapen, G.R. (1977): Factors influencing lysozyme determination by lysoplate method. Clin. Chim. Acta.; 74: 217255.

Persijin, J.P. and Slik, W.V. (1976): Kinetic method for determination of gamma glutamyl transferase. J. Clin. Chem. Biochem.; (14): 421-I428.

Puhac, I.; Ha-govic, N.; Stenkovic, M. and Popvic, S. (1963): Acta, Veteran., 13-30.

Reid, T.M.; Daniel, I.F. and Lawence, A.L. (1994): Mutagenesis by metal induced oxygen radicals. Environ. Health Prespect.; 102 (suppl 3): '7"I I 57-61.

Ribadeaodomas, A.R. (1972): Eur. J. Biochem. 25: 505.

Robins, T.G.; Bornman, M.S.; Ebrlisb, R.I. (1997): Semen quality and fertility of men employed in a South Africa lead acid battery plant. Am. J. Ind. Med.; 32: 369-376.

Satob, K. (1972): Determination of malondialdeh de by colorimetric method. Clinical Chimica Acta; 90: 37- 41. 
Saxena, D.K.; Mort by, R.C.; Lal, B. and Chandra, S.V. (1989): Lead I.induced testicular changes in protein malnourished rats. Folia c'c. Histochem. Cytobiol.; 27(1): 57-61.

Schmid, H.H. and Walter, M. (1994): No at work. Cell: 78: 919- 925.

Simsek, N.; Karadeni, Z.A.; Kalkan, S.; Keles, O.N. and Unal, B. (2008):

Spirulina platensis feeding inhibited the anemia and leucopenia induced lead and cadmium in rats. J. Hazard Mater.; Sep. 2 E pub ahead of print.

Snedecor, G. and Cochran, W. (1980): Statistical methods, 6 thed. The lowastate, Univ. Press, Ames, Iwoa, U.S.A.

Soares, E.R.; Sheridan, W.; Haseman, J.K. and Segall, M. (1979): Increased frequency of aberrant sperm indicators of mutagenic damage in Mice. Mut. Res.; 64: 27-35.

Sokol, R.Z. (1987): Hormonal effects of lead acetate in the male rat: Mechanism of action. Boil. Reprod.; 37: 1133-1138.

Sokol, R.Z.; Madding, C.E.; Swerdioff, R.S. (1985): Lead toxicity and the hypothalamic-picture testicular axis. Bioi. Reprod.; 33: $722-778$.

Springer, N. (2005): Influence of dietary protein composition on lead absorption in rats. Bulletin environmental contamination and toxicology (May) P. 1-127.

SPSS- 14 (2006): Statistical package for social SPSS for windows release 14. 0.0, 14; June, 2006 Standard Version, Copy -right SPSS Inc., 1989-2006.

Srinivas, S.; Kaol, P. and Pakash, V. (2007): Mechanism of interaction of BP (11) with Milk proteins: a case study of alpha-casein. J. Agric. Food Chem.; 31, 55(22): 9283.

Todd, A.C. (1994): Lead poisoning. West. J. Med.; 161: 187-190.

Tuorma, T.E. (1995): The adverse effects of lead. J. Orthomol. Med.; 10: 149-164.

Vig, E.K. and Ho, H. (2000): Lead toxicity in older adults. J. Am. Geriatr. Soc.; 48: 1501-1506.

Vorma, M.M.; Joshi, S.R. and Adeyemi, A.0. (1974): Experient.; 30-486.

Waites, G.M.H. and Gladwell, R.T. (1982): Physiological significance of fluid secretion in the tests and blood testis barrier. Physiol. Rev.; 62: 624-671.

Zelikoff, J.T.; Parsons, E. and Schlesinger, R.B. (1993): Inhalation of particular lead oxide disrupts pulmonary macrophage mediated function important for host defense and tumor surveillance in the lung., Environ. Res.; 62(2): 207-22. 